\title{
Fiction and Social Knowledge: Towards a Strong Program in the Sociology of Literature
}

\author{
Jan Váňa \\ PhD Student, Department of Sociology, Faculty of Social Studies, \\ Masaryk University, Brno (Czech Republic) \\ Address: Joštova 218/10, Brno, 602 oo, Czech Republic \\ E-mail:vana@fss.muni.cz
}

\begin{abstract}
Following the strong program in cultural sociology, I propose a strong program in the sociology of literature, which treats literary pieces rightly as relatively autonomous cultural entities and "independent variables". To outline the epistemological foundations of the new research program, I compare how social knowledge comes into existence through the sociological text and the text of literary fiction. I discuss the representation of social reality in interpretive research, with Isaac Reed's book Interpretation and Social Knowledge as a starting point. To claim literary autonomy, I outline some of the aspects which social theory shares with literary fiction. I am mainly interested in how social theory and literary fiction mediate social knowledge to their readers via the aesthetic experience. I identify two main categories of social knowledge mediated by literature: existential understanding and Zeitgeist. Discussing the sociological treatment of several novels, I look at how these two categories intertwine and support each other to create colorful, sensitive, but also robust and deep social knowledge, which condenses aesthetic, existential, and non-discursive aspects of social experience together with the "big picture" of whole societies. I argue that only by overcoming the oftenassumed inferiority of literature in sociological research can sociology realize its full potential in understanding the meanings of social life.
\end{abstract}

Keywords: sociology of literature, cultural sociology, social knowledge, social theory, theorizing, aesthetic experience, fiction

\section{Introduction}

\begin{abstract}
"Novels ... tell us different things about social life from the things a piece of sociological research can tell us about social life, and to the extent that they tell us these different things, they tell us more things. ... The knowledge they can convey about society is no substitute for the methodical knowledge of social science; but neither is it inferior or subordinate to the latter." (Harrington, 2004: 3f.)
\end{abstract}

I advocate for an innovative approach of looking at cultural meanings in a society of a given time and space through the lenses of literary fiction. Literary texts communicate social experience using a form of phenomenological reduction, which brackets out certain phenomena and emphasizes others. This is based on several factors such as the author's intentional and non-intentional choices in the writing process, decisions made by various 
actors in the production chain of the book, and the socio-cultural background of the involved actors. All these factors are concentrated within an activity that I call imaginative theorizing, a process that transforms certain social experience into the resulting fictional text through a set of intuitive and conceptual tools and literary devices. Then, the literary meaning is communicated in the form of aesthetic experience. Readers who initiate the reading of a novel can access this experience through emotional engagement with the text maintained by literary devices such as metaphors, simile, rhythm, pace, and phonetic aspects. Due to the aesthetic experience of reading, literary fiction-unlike historical, social scientific, or journalistic accounts-is well suitable for studying socio-cultural phenomena with special emphasis on their aesthetic, experiential, and existential qualities. Immersed within the aesthetic experience, the readers of literary fiction can understand how it is to live in a particular society by feeling it, rather than knowing it.

However, if sociologists of literature want to access these volatile features of social life mediated by the aesthetic experience of reading, they must profoundly scrutinize the epistemological foundations of currently dominating paradigms. In the past, the sociology of literature has treated literary texts as reflections of supposedly more substantial social forces. The Marxist heritage developed into several schools, such as the field theory of Pierre Bourdieu (1996), the "art worlds" of Howard Becker (1982), and the cultural industry within the British cultural studies, which approach literature as a "product" subordinate to social interactions and institutions (see Váňa, 2020b). Even studies declaring the priority of cultural meaning over institutional arrangements look at literary works as rather mysterious black-boxes subordinated to their social context, such as Wendy Griswold's (1987) "fabrication of meaning", or the "cultural sociology of reading" recently established by M. Angélica Thumala Olave (2018). Sadly, the predominance of these paradigms prevents sociology from looking at literature as an autonomous agent that actively shapes cultural meanings and has a great potential to provide full-fledged and self-dependent social knowledge.

In this article, I outline the epistemological foundations of a new "research program which would be a powerful alternative to mainstream paradigms in sociological studies of literature" (Váňa, 202ob: 2). Following the strong program in cultural sociology (Alexander, Smith, 2003), I propose a strong program in the sociology of literature which treats literary pieces rightly, as relatively autonomous cultural entities, "independent variables" resisting the judgmental eye of an analyst, while allowing strong explanatory theories to infer knowledge about general social phenomena.

Jeffrey C. Alexander and Philip Smith (2003: 15) introduced the strong program to remedy the "numbness toward meaning" from which sociology "has suffered" for "most of its history". The three principal pillars of the strong program are: a commitment to cultural autonomy, which calls "for a sharp analytical uncoupling of culture from social structure" (Ibid.: 13); a requirement to bracket-out the "wider, nonsymbolic social relations" driven by the Geertzian "thick description", which allows for a reconstruction of an "internal pattern of meaning"; and an "imperative of identifying concrete mechanisms through which culture does its work" (Ibid.: 23). As I will show, with the help of 
Isaac Reed's (2011) conceptualization of social knowledge, literary works function like texts written by cultural sociologists in many ways. They fulfill the principle of analytical "bracketing out" borrowed from Husserlian phenomenology as well as Clifford Geertz's (1973) thick description to communicate "a social phenomenology" (Felski, 2008: 88), which allows for a reconstruction of "internal pattern of meaning" - that is, a creation of "the analytically autonomous culture object" (Alexander, Smith, 2003: 14). Also, literature fulfills the imperative of probing for deep and unconscious cultural structures. Literary works mediate deeper understanding through complex systems of fictional and real references through "semantic mapping of their contents upon the actual world" (Pavel, 1986: 84), but not only that. Literary fiction provides access to hitherto inaccessible qualities of social life; it can "communicate thoughts [about social life] that scientific discourse could not" (Harrington, 2002a: 55).

My claim is that literary fiction does not need to be gutted by sociological theory in order to provide social knowledge. The task for a strong program in the sociology of literature is to recognize the social knowledge which is already implicitly present in literary works without translating it into sociological discourse. "Cultural sociologists can find in literature a powerful ally for understanding the social world, but only if they respect that in this complex organism 'the meaning emerges of its own volition' (Hoggart, 1966: 281) and cannot simply be dissected without being damaged. What is essential is that the literature must speak for itself” (Váňa, 2020a: 195).

To claim for literary autonomy, I outline some of the aspects that social theory shares with literary fiction. Particularly, I am interested in, first, the ways how both social theory and literary fiction come into existence, and second, how can they mediate social knowledge to their readers. I argue that only by overcoming the assumed inferiority of literature in sociological research can sociology realize its full potential in understanding the meanings of social life.

\title{
Social Theory and Aesthetics of Social Experience
}

Social Theory and Theorizing as a Craft

\begin{abstract}
"Theories are nets cast to catch what we call 'the world': to rationalize, to explain, and to master it. We endeavor to make the mesh ever finer and finer." (Popper, 2005/1934: 37)
\end{abstract}

Gerard Delanty (2009: 19f.) claims that the emergence of social theory "coincides with the emergence of modernity" and it properly "begins with the recognition that society is a reality in itself". The roots of social theory are connected with enlightenment, which was, on the one hand, positively embraced as a way of looking for rational solutions for press-

1. My position is different from Sanderson's (2005: 2f.) suggestion that "sociological" theory is more concerned with understanding society while "social" theory with "criticizing and rebuilding". I use the terms "social" and "sociological" theory interchangeably, based on the context and the theorists I refer to. When it comes to my original claims, I follow Reed (2011) in using "social” theory. 
ing social issues of modernity (e.g., Comte's positive sociology), and on the other hand, criticized as a knowledge-centered ideology (most significantly by Marxism). Either way, the development of social theory has been revolving around questions of social order, social action, and social change, and the principles of their functioning (Joas, Knöbl, 2009: 18). Piotr Sztompka (2004) asserts that one of the primary goals of a theory is explanation. Especially "in times of change" there is "a pressure on sociologists from both the common people and politicians to provide explanations of the chaos"-to answer questions such as "where we have come from, where we are, and where we are going" (Ibid.: 26off.). ${ }^{2}$ One of the main tools for answering such questions, which sociology borrowed from the natural sciences, is a testable hypothesis. Hence Karl Popper's (2005/1934) famous criterion of falsification (cf. Baert, Rubio, 2009: 63f.).

However, later it was argued that the idea of empirical evidence and theoretical knowledge as two discrete systems, which was adopted from the natural sciences, is too simplistic for social sciences (see Reed, 2010: 21f.). This statement is related to the argument that theorizing as a way of making theories is not an exclusive discipline of scientists but a facility of every individual. "[T]he construction of theories, of generalizing statements" is not only a "significant component" of science, but it "is a common human ability to make sense of disorderly flow of everyday experience"; theories in everyday life are "necessary" as they are "unavoidable" (Joas, Knöbl, 2009: 4ff.). It is then impossible to distinguish purely "empirical" entities from purely "theoretical" assumptions. General presuppositions, models, concepts, etc., blend with empirical observations, correlations, and methodological assumptions so that they mutually influence and co-constitute each other. That is why Alexander (1982: 2) talks about the "epistemological continuum" rather than a binary opposition. To say that theorizing is a general facility of every individual neither decreases the value of scientific theorizing, nor does it imply that there is no difference between scientific and non-scientific theorizing at all. Surely, social scientists have their institutionalized ways to ensure that their theories will be acclaimed by the scientific community as reliable and valid. Nevertheless, the scientific rigor is not what renders the scientific finding more "realistic" or truthful. There is a crucial ingredient without which any theorizing would merely be patching old ideas together. This ingredient is (sociological) imagination.

Since C. Wright Mills (1959) wrote his seminal piece, sociologists praised sociological imagination as almost a miraculous power. According to Sztompka (2004: 255ff.), sociological imagination is a "complex skill or ability" allowing its owner, among other things, to "understand deep, hidden, structural, and cultural resources and constraints that influence social life ... perceive social life in its 'social becoming"' and "recognize the tremendous variety and diversity of the forms in which social life may appear." Sztompka (Ibid.: 256) recognizes "the training of the sociological imagination . . . to be absolutely crucial for the education of sociologists". There is a very close relationship between theory and sociological imagination, which lies in "using theory" as a "concrete experi-

2. This has always been a crucial endeavor of literature, too. In its early stages, sociology competed with literature in being the leading voice for modern society (cf. Lepenies, 1988). 
ence" (Ibid.: 257). That is why Mills (1959: 224) talks about sociological imagination as a "craft" - a practical knowledge sociologists learn by executing it. The "craft of theorizing" (Swedberg, 2014: 16), as a craft of creating and using theories, is not something we can achieve through following sociological rigor, but something we need to absorb through our experiencing the social world.

In the social sciences, theory-making is often reduced to following formalized steps of scientific procedure, which is, nevertheless, only a (less interesting) part of the story. The other part is connected to tacit knowledge, intuition, and implicit proficiency (Knorr Cetina, 2014: 33). This side of theorizing relies much more on unintentional and unconscious activities, as we often do not know "what we may be doing when we don't follow procedures and yet come up with theoretical knowledge" (Ibid.: 30). These processes are not navigated by a method but by the researcher's intuition and feelings. Karin Knorr Cetina (Ibid.: 55ff.) suggests that theorizing requires "full concentration" as well as "pleasurable feelings and emotional rewards", which are brought together in a flow of research activity. Emotions are fundamental for theorizing, as they not only provide motivation for the research, but they navigate us through "moment-to-moment processing and decision making" (Ibid.: 58). Emotions are our very compass, which leads us through the immensely broad sea of possible research choices.

According to Richard Swedberg (2014: 12), the unconscious part of theorizing stems from an "object of perception" with "great associational potency", which arouses in the perceiver a "tendency to call up ideas" (Peirce, 1992: 182). Charles S. Peirce illustrates this in his observation of an impressionist painting. At first, the painting "has a very disagreeable look and seems very meaningless", but after he immerses himself into it, Peirce (1992: 182) finds himself "sniffing the salt-air and holding up [his] cheek to the sea breeze". The act of contemplating upon the painting brings up new, unexpected associations, which widen the horizon of its creative interpretation, or, in other words, of creating a theory about the painting. Etymologically speaking, Swedberg (2014: 12) claims that "theorizing according to the Greeks means that you concentrate on a phenomenon and stay with it, in this way trying to understand it". In his famous article, Robert Nisbet (1962: 69) reminds us that the word theory, in its original sense, stands for contemplation and is closely allied with imagination, that is, "internalising the outer world to an image" through the "detachment" of the author. Imagination allows for a conceptual understanding of the world "in the process of semantic innovation", which occurs through a perpetual oscillation "between distance and proximity, between remoteness and nearness" (Ricoeur, 1978: 148f.). Theorizing is an ability to delineate "[b]ackground, detail, and characterization" of a particular social phenomenon and transform it "into something that is iconic in its grasp of an entire social order" (Nisbet, 1962: 72). According to Nisbet (1962: 71), the ability to understand the social world through imagination is more of an art than a procedure because it relies heavily on an "intuition" and "imaginative grasp", which are "only partly conscious". 


\section{Metaphors and Aesthetic Devices: Writing Social Experience "Down and Up"}

Classical sociologists like Durkheim and Simmel could arrive at their influential theories only through "ways more akin to those of the artist than those of the data processor, the logician, or the technologist" (Nisbet, 1962: 72). That is also why we find it hard or even impossible to condense, generalize, and systematize the writings of sociological classics. What we read in their texts is the way they were theorizing (i.e., contemplating, thinking through) social phenomena to understand it. This is especially apparent in Simmel's work. The texts of famous sociological "impressionist" (Lepenies, 1988: 240) are so compelling and well-acclaimed as they rely heavily on the aesthetic dimension of the text rather than an effort to rigid systematization (cf. Adorno, 1991). However, the imaginative and aesthetic dimensions are necessarily present in other sociological works as well, be it great sociological founders or contemporary thinkers. The most telling example is the sociological use of metaphors. Charles Turner (2010: $2 \mathrm{f}$.) reminds us of well-known metaphors such as Weber's "shell as hard as steel", ${ }^{3}$ Marx's "womb of the old society", Isaac Newton's "on the shoulders of giants" thoroughly inspected by Merton (1993), or master metaphors "in which society 'itself' is imagined 'as' something: organism, cybernetic or autopoietic system, drama, game, text”. Turner refers to Geertz's (1983: 22) definition of metaphor as "a way of talking that works well in one field of inquiry and that is employed in an attempt to make sense of something in another field of inquiry". For sociology, the metaphors of organism and system, which have been taken from biology, serve to comprehend society despite its general elusiveness (Turner, 2010: 3 ).

Metaphors in sociology do not make us understand something better, but they are necessary to understand something at all. Unlike natural sciences, which according to Turner (2010: 7) are governed by the logic of argumentation and discovery, social science cannot do without "the logic of invention" based on metaphors. The "original basic intuitions", which the social scientist has about the social world, must drive the "original impulse" towards the creation of a social theory (Ibid.: 7). Metaphor, then, is not a "mere decoration"- $\mathrm{a}$ "witty aside or pregnant summary"-but it is a crucial constituent of the whole theory; the metaphor might even organize an "entire body of inquiry" on the level of discourse, such as Erving Goffman's metaphor of "drama” (Ibid.: 23). In this sense, Paul Ricoeur (1976: 67) suggests, the language of social science has in common with poetic language that "it only reaches reality through a detour that serves to deny our ordinary vision and the language we normally use to describe it" (cf. Brady, 2004: 629). When authors like Goffman write about social life metaphorically (e.g., society as a theater), they use a "heuristic fiction" to reach a "reality more real than appearances" (Ricoeur, 1976: 67 ). In other words, similar to literary authors, social scientists invent new metaphors to address phenomena that are real yet hitherto inaccessible.

Importantly, this applies not only to metaphors but to aesthetic devices of the text in general. The structure of sentences, the order of words, the concrete use of word forms

3. Originally translated from German by Parsons as "iron cage". However, this translation changes the meaning of Weber's original term "stahlhartes Gehäuse". 
(passive and active verbs, prepositions, adverbs, etc.), and the rhythm and pace of the text make it possible that the author communicates an experience of social phenomena to the reader. A good example of such communication is ethnographic research. According to Paul Atkinson (1990: 6of.), the ethnographers' account of social phenomena results from two steps: in the first step, the ethnographers "write down" their experience of the field and in the second step, they "write up" the notes into an interpretation. It might seem that the first phase is somehow closer to the unreflected sense of experienced reality, while the second phase is more of a construction. However, both phases "involve the creation of textual materials" and both "are equally matters of textual construction" (Ibid.: 60). There is no purely descriptive writing. By taking a note, the ethnographers already filter their experience through presuppositions, selection criteria, a particular style of textual construction, etc. An impression of reality and authenticity, which is often valued in ethnographic texts, results from skillful construction rather than a rigidly realistic description. What we might think of as a mere aesthetic garnish (the style) decorating a more fundamental content (the "real" description), as a matter of fact, "contains within it the analytic message of the sociology itself" (Ibid.: 62).

\title{
Aesthetic Experience of Reading the Social
}

\begin{abstract}
"What [cock fight] does is what ... Lear and Crime and Punishment do; it catches up these themesdeath, masculinity, rage, pride, loss, beneficence, chance-and, ordering them into an encompassing structure, presents them in such a way as to throw into relief a particular view of their essential nature." (Geertz, 1973: 443)
\end{abstract}

A prominent example of an ethnographic account that greatly relies on its aesthetic form is the famous work by Clifford Geertz (1973), "Deep Play: Notes on the Balinese Cockfight" (hereafter Deep Play in italics). Although an iconic anthropological text, Geertz's piece served as a platform on which literary critics in the 1980s developed the research program entitled the New Historicism. In a detailed analysis of Geertz's text, the literary historian Stephen Greenblatt (1997: 20) shows that it is not the anthropologist's method that makes his text so powerful but rather "the lived life that he managed so well to narrate, describe, and clarify". The pleasing aesthetic experience of a reader who engages Geertz's work has a considerable impact on what Greenblatt calls a "reality-effect" (Ibid.) and is the reason why we read Deep Play as truthful. The notion of the "reality-effect" has important implications for literary studies: "[Geertz's] thick descriptions of cultural texts strengthened the insistence that the things that draw us to literature are often found in the nonliterary, that the concept of literariness is deeply unstable, that the boundaries between different types of narratives are subject to interrogation and revision" (Greenblatt, 1997: 21; emphasis mine).

According to Melissa Freeman (2014: 829), a key to the interpretation of Deep Play is an "aesthetic experience", which takes place when the ethnographer enters a dialogue 
with the field. The aesthetic style of the ethnographic text is, to a considerable degree, driven by the ethnographer's interpretive engagement with the field. "An image, fiction, a model, a metaphor, the cockfight is a means of expression; its function is neither to assuage social passions nor to heighten them . . . but, in a medium of feathers, blood, crowds, and money, to display them" (Geertz, 1973: 444). What Geertz once experienced and conserved by his thick description can be revived and experienced in a new way in a dialogue with his text. It is only thanks to the "aesthetic manifestation" of his essay that we can get closer to the meaning, which was once part of the unique circumstances and now is inaccessible (Freeman, 2014: 832). The engagement of the reader, the author, and the topic triggers the aesthetic experience, which, consequently, facilitates the interpretive dialogue of understanding.

In Deep Play, the use of aesthetic devices for conveying the social scientific account is exceptionally visible, but we can find the same in other ethnographic texts, too. Ivan Brady (2004: 629f.) likens ethnography to poetry, as they both "metaphoriz[e] experience" in "a self-revealing, self-constructing form of discovery". This metaphorization of experience occurs as the ethnographers, just like poets, are immersed in their sensual perception of the social surrounding. When put into a text, the ethnographic account, just like the lyrical, relies on the ethnographers'/the poets' ability to process their experience imaginatively so that the reader can touch, smell, hear, taste, and see the scene just like the author did.

The key term here is emotional engagement (Abbott, 2007). The author of the text, be it a poet or an ethnographer, is emotionally engaged with the concerned social phenomena. Then, to communicate the experience to the reader, the author writes for the reader to be emotionally engaged with the text. The emotional engagement is important because it elicits the indexical here and now of the communicated experience. Thanks to the author's skillful use of metaphors and other aesthetic devices, the reader, who makes an effort to read, gets immersed within the text. Losing distance from a "mere description" channels the feeling of the researcher's here and now to the reader. This is what Andrew Abbott (2007: 94) calls an "indexical emotion", an "intense engagement" of the author and the reader in the "indexical, located quality, the transitory and particular nature of [the text's] present here(s) and now(s)". The "indexical emotion" is a link that enables the reader to relate to the subjective experience and feeling of the author. At the end of the day, the indexical emotion is what evokes in the reader the feeling of truthfulness-a "reality-effect" (Greenblatt, 1997: 20) - a deeply subjective experience of knowing the world outside the text through reading the text. 


\title{
Social Knowledge in Literary Fiction
}

\author{
Social Knowledge in Pride and Prejudice
}

\begin{abstract}
"Both the artist and the scientist are driven by the desire to understand, to interpret, and to communicate their understanding to the rest of the world." (Nisbet, 1962: 69)
\end{abstract}

I have shown that sociology embraces intuition, emotion, and aesthetics-the attributes usually connected to literariness and lyricism - to mediate social knowledge to the reader. Now, the argument with literature goes the other way around: I will show how literary texts, through their imaginative theorizing, can come at a kind of knowledge which is equally, if not more, valuable for sociologists as knowledge provided by sociological studies.

In a chapter called "Jane Austen: The Novel as Social Analysis", Becker (2007: 241) observes how in Pride and Prejudice "Austen has presented us with a well-constructed analysis of the marriage customs of a particular group of early-nineteenth-century English country gentry". The well-known novel follows a short period in the lives of the Bennet daughters, who are subject to the social conventions and expectations connected with women's role in society, family, and partnership of a specific social class and cultural milieu. Austen's realistic style makes it easy for the reader to identify with the storyline, even though there is no clear "evidence" that the stories happened. The "complex web of connected observations" (Ibid.: 242) is conveyed in such a way which, on the one hand, gives the readers an impression of situations well-known from their lives, while, on the other hand, transcends these particular situations and experiences into something more general with a quality of "the larger truth" (Ibid.: 247).

To make his point that "novels can have, in addition to their qualities as literary works, qualities as social analyses", Becker (Ibid.: 250) makes a few observations. First, the realistic account of social life conveyed by Pride and Prejudice creates the sense of a truthful social analysis not because of its method or reliable source of data but because of its ability to "make sense" (Ibid.: 248) via its fictional writing. The sense of authentic reality-the "verisimilitude" (Ibid.) - is ensured by using fictitious entities and textual devices in combination with a plenitude of realistic details and observations. Second, Austen does not present the analytical findings in the form of "neatly labeled conclusions to which she then attaches probative evidence" (Ibid.: 249). Rather, "the reader performs an analysis" as he or she "absorbs [the presented] details and thinks about them, about how they are connected" (Ibid.). The analysis is not reducible to content or information. The social knowledge that we obtain through the novel does not have easily "paraphraseable" (Ward, 1986: 335) meaning. "As we read the stories of the various couple's finally getting together," says Becker (2007: 245), "we see how contingent the process is, how many 
things can go wrong, how many misunderstandings can prevent a union, how many disapproving relatives can intervene".

The social knowledge, which we get through the reading, is indexical in the sense of Abbott (2007) as outlined above. But it is also general and abstract, as it tells us about the respective social system and principles of its reproduction. Both the indexical and the general unfolds within the reading process in the dynamic interaction between the reader and the novel. The social knowledge is accessible through the reading of the novel. It develops with every new sentence we read, as we "look to the clues Austen gives [us]" (Becker, 2007: 249). We "assess likelihoods, develop expectations that may or not be fulfilled" (Ibid.) - we are challenged and puzzled. Simply put, social knowledge emerges in an active dialog between Pride and Prejudice and its reader.

\section{Social Knowledge in Literary Fiction: Problem of Explanation}

In what way can we claim that literature provides social knowledge? Following the paradigm of meaning-centered interpretive sociology, I am interested in a kind of social knowledge that Reed (2011: 10) defines as "interpretive social knowledge". Theorizing, which can generate social knowledge, is a perpetual intersecting of two meaning-systems-the theory and the evidence. This intersecting occurs according to the principle of "epistemological continuum" as introduced by Alexander (1982) (see above). The entities which belong to the meaning-system of evidence are never "verifiable by literal observation but must be inferred and understood in a dialogue about what is happening or has happened"- they are always already constructions of some sort (Reed, 2011: 16).

Here, Reed (2011: 130) comes with an elegant solution to the interpretation/explanation dilemma, ${ }^{4}$ stating that the two are not mutually exclusive. ${ }^{5}$ Rather than looking for a causal effect between forces, the investigator interprets the meaningful surroundings of a particular inquired social fact. Then, the investigator comes to an explanation of the social fact as an understanding of that unique constellation of meanings, which allowed for that social fact to happen. The contextually-rich interpretation of a case-as in the sense of Geertzian thick description-provides an explanation that makes sense within the interpretive framework of that case.

Such a definition of social knowledge has an important implication for literary fiction. Through her imaginative theorizing, Jane Austen describes "the arrangements of signification and representation, the layers of social meaning, that shape human experience" in order to reconstruct "the meaningful context of social action" (Reed, 2011: 10). The thick description allows Austen to portray the marriage customs of a social group as forming factors,${ }^{6}$ through which she can explain repertoires of people's actions. When reading

4. Interpretation in the sense of hermeneutic understanding, explanation as searching for causality (further see Reed, 2011: 123-162).

5. Interpretation is often unjustly claimed as not being able to provide social knowledge (Reed, 2011: 92).

6. Originally, Reed (2011: 143) talks about "forming causes". However, I agree with Dominik Bartmański's and Werner Binder's (2015: 508) suggestion to replace Reed's notion of "cause" with a "more nuanced repertoire" of language. 
Pride and Prejudice, the reader approaches the thickly described social reality as an interpretation of characters, events, and actions within a specific spatio-temporal setting. ${ }^{7}$ This usually occurs implicitly (supposing that the reader is not a literary scientist) in the course of the reading experience as the pace and the rhythm of the text lead the reader through paragraphs, sentences, and word combinations. The explanatory dimension of social knowledge emerges continuously as the reader encounters the text.

\title{
Literature as Existential Understanding
}

\begin{abstract}
"How, at last, has someone solidified what has always escaped-and made it too into this beautiful and perfectly enduring substance?"

Virginia Woolf on behalf of Proust's iconic saga (Zhang, 2014: 66).
\end{abstract}

Numerous social scientists suggested that the ability to theorize the social is common both to sociologists as well as artists and literary authors (e.g., Alworth, 2015; Erasga, 2010; Harrington 2004; Kurakin, 2010; Kuzmics, 2015; Nisbet, 1962; Swedberg, 2014). Overall, we can distinguish such definitions into two main categories: first, literature is a way to grasp the emotional, subjective, and tacit aspects of social experience, which are prone to slip unnoticed by sociological analysis; second, literature is a way to access a deeper understanding of social phenomena, which is representative of the collective life in a broader socio-historical milieu. The former channels the existential understanding of social experience, while the latter anchors this experience in more general cultural patterns of social life-i.e., what we usually understand by the term Zeitgeist. ${ }^{8}$

As for the existential understanding, cultural sociologist Thumala Olave (2018) conducted her project "towards cultural sociology of reading" with an interpretive analysis of women's reading experience in the UK. She focused on "the subjective and existential meanings of the experience of reading" (Ibid.: 419), which allowed her to see how "the aesthetic and the cognitive work together" (Ibid.: 429). As the readers get immersed into the reading process navigated by the aesthetic devices, they experience enchantment and pleasure of reading. Simultaneously, these alternate with moments of "recognition", which invite the readers to see their inner self and their position in the world with a new perspective (Ibid.). The understanding that comes into play is different from a cognitively acquired knowledge, as it is triggered in the flow of reading experience and to a great extent anchored in the readers" "emotional reflexivity".

However, in contrast to social knowledge, Thumala Olave's perspective is too focused on the "self-knowledge" of the reader, such as "self-understanding," "ethical reflection and social bonds," and "self-care" (Ibid.: 429-432). However, there is much more to the literary fiction than a mere "reinventing myself" (Macé, 2013: 215) agenda. Literature mediates existential knowledge, which is inherently social and intersubjective. The emotion

7. This setting can be highly "fictitious" or unspecified, yet it always relates to "real" concepts in the authors' and the readers' minds.

8. For a more systematic elaboration on Zeitgeist as a sociological concept, see Krause (2019). 
bound to the reading process is a part of a "structure of feeling" (Williams, 1960: 42) referring to a broader socio-historical background. In this sense, Rita Felski (2008: 91f.) talks about "deep intersubjectivity". "Deep intersubjectivity connects the reader's "selfunderstanding" facilitated by emotions in the reading process with the intersubjective aspect of the emotional experience. "The technique of deep intersubjectivity," claims Felski (2008: 92), let us see "particular societies 'from the inside'; we come to know something of what it feels like to be inside a particular habitus, to experience a world as self-evident, to bathe in the waters of a way of life".

Reading serves not only for "literary experience [to become] a resource for stylizing the self" (Macé, 2013: 222) and a tool for "introspection" (Zhang, 2014: 58), but it is a way of learning about the experience of people living in a given time and place, who are different from us. Austin Harrington (2002b: 62) points out that writers "are important for sociology because their stories and depictions tell us about aspects of social life ... in the context of individual life experiences". Smith (2004: 106) demonstrates this claim reading Marcel Proust (2002), whom he proposes "as a phenomenological corrective" for Bourdieu, who has been criticized many times for "stripping away all the existential depth" (Lahire, 2015: 405) in literary works he studied. According to Smith (2004: 108ff.), we can "detect in Proust's work ... the prototype for Bourdieu's inquiry," which Proust develops to "a systematic phenomenology of human action and mental life as well as an implicit cosmology of class". Through the aesthetic devices of irony and cynicism, Proust depicts social life as a power struggle of social actors motivated to maintain and reproduce their wealth and social status (social and economic capital in Bourdieusian vocabulary). However, the existential depth with which Proust endows his fictional characters is different from Bourdieu's account of the actors' subjectivity. Bourdieu has been criticized for seeing the existential reality of people occupying various positions in the field of power struggles as just actors' subjective idea of their positions and dispositions underlaid by objective structures (e.g., Lahire, 2015; cf. Smith, 2004: 105f.). Proust's model of stratification does more than giving actors an illusion of agency. "Bourdieuvian themes" of class distinction exhibited through "differing uses of the body, language and diversified systems of taste" in Remembrance of Things Past ${ }^{10}$ are intertwined with "a more thoughtful theorization of contingency, change and identity"; while in Bourdieu's theory, the existential is subsumed to the structuring logic of habitus, Proust offers "a more balanced picture of life, with oscillations between habituated action and reflexive self-awareness" (Smith, 2004: 109f.).

The existential understanding mediated by literary fiction is closely related to sensitivity and empathy through which the author can document the "fleeting experiences" (Harrington, 2002a: 57) of social reality and communicate them through delicate work with language. To mediate such an understanding is a matter of theorizing as a craft as introduced above-a skill to be learned by practicing it. The sensitivity in writing fiction requires that the author be capable of distinguishing more stable patterns of human behavior from its transient manifestations. That is why social scientists, but also readers

9. A term originally coined by Butte (2004).

10. I follow the first English translation of the saga's title used by Smith. 
in general, often say that writers "sensitize us to certain aspects" of social life "that would otherwise remain in the dark" (Petersen, Jacobsen, 2012: 115). Through skillful writing, the authors can convey their sensitivity towards a topic to the reader engaged in the reading process.

David J. Alworth (2014) reminds us how Goffman (1962) used Herman Melville's novel White-Jacket (1956) in his seminal piece Asylums. Goffman refers to Melville's novel in several ways: as an example of his total institutions; as a "kind of evidence" and "repository of sociological data"; and as "means of apprehending sociality" through micro-situational textures of social experience (Alworth, 2014: 237). However, Goffman was mainly impressed by the aesthetic qualities of Melville's novel and how they portrayed social interaction in a condensed, yet very subtle way. Goffman, who "was drawn to the novelist as an intellectual ally: a fellow student of the interaction order", recognized Melville as "unusually sensitive to sociality and social typologies" (Alworth, 2014: 246-255). This sensitivity is, first of all, expressed in Melville's use of aesthetic textual devices. And only through these aesthetic devices was Goffman able to adopt Melville's sensitivity "to construct [his own] conceptual vocabulary" (Ibid.: 241). That is, the social knowledge that Goffman acquired through Melville's text was to a great extent based on the way Melville wrote. "[T]he ebullient voice of the narrator; the striking imagery of the ship; the embellished descriptions of character; the thematic structure", says Alworth, deploy White-Jacket "toward the production of sociological knowledge" (Ibid.: 235). ${ }^{11}$

\section{Literature as Representation of Zeitgeist}

The second category of social knowledge provided by literary fiction is the literature as a representation of broader social phenomena-an expression of Zeitgeist. This category is well exemplified in The Man Without Qualities by Robert Musil (Harrington, 2002a, 2002 b) and sociological interpretation of Milan Kundera's Immortality (Atkinson, Silverman, 1997), but we can find it also in Proust's Remembrance of Things Past. In what sense can a novel represent social life as a general phenomenon?

Harrington (2002b: 67) states that the "world" of The Man Without Qualities (Musil, 1953) can be read "as a fictional representation of the many aspects of complexity and interconnectedness, of 'forms of sociality' and 'stylization of life', of reification, and aestheticism that Simmel describes in The Philosophy of Money; as well as from Peter Berger's (1970) analysis of perspectivism and 'multiple realities' in Musil through the lens of Schützian phenomenological sociology". At the same time, Harrington (2002a: 57) argues that he chose the novel for his analysis because it "articulates a whole range of political changes and cultural discourses emerging from the fault-lines of central Europe and the crumbling Austro-Hungarian empire around the time of the First World War". As we can see, the enumeration of "qualities" of The Man Without Qualities is rather long. There is a reference to a particular time frame and place which implies large societal

11. I conceive Alworth's notion of "sociological knowledge" as interchangeable with the term "social knowledge" as used by Reed, which I believe is more suitable since it does not imply that such knowledge is obtained exclusively through the methods of sociological inquiry. 
changes on many levels. There is also a list of more abstract attributes of the "world", which the novel "represents", such as "complexity", "reification", and "stylization". Harrington uses these abstract terms to point out that Musil does not merely describe the 1910s Europe inhabited by his fictional characters, but he goes way beyond historical facts. Musil combines historical facts with his intuitive understanding of the world-his theories in terms of Reed (2011). Harrington admires Musil's ability to "captur[e] Zeitgeist," to "captur[e] the sense of immense space-time contraction in modern social life" (Harrington, 2002a: 57), and "to explore the psyche of his age" (Harrington, 2002b: 66). All of these terms - "Zeitgeist," "space-time contraction," and "psyche of an age"-refer to Musil's ability to mediate a deeper understanding (in the sense of forming meanings) of the 1910 s Austro-Hungarian Empire's social milieu. Through his intuitive theorizing, $\mathrm{Mu}-$ sil employs "theoretical signifiers" upon historical "facts" and events in order to produce heavily condensed claims about these historical facts and events. The evidential signifiers (or, as Reed says, "minimal interpretations") are re-signified into maximal interpretations, which mediate "deeper understanding" (Reed, 2011: 23). We can also allude back to Geertz's thick description to stress the immense "thickness" of Musil's text: it is a skillful description of a specific, micro-situational behavior of fictional characters that makes it possible to mediate a deeper understanding of whole societies.

In Kundera's Immortality (1991), the social representativity mediated by the novel is a bit different. Rather than grasping society in its complexity and multiplicity, Kundera (1991: 127) invents his own theoretical concept, "the imagology", to analyze a particular social phenomenon he considers symptomatic for the whole of Western society. Paul Atkinson and David Silverman (1997: 306) then examine Kundera's "discussion of how the subject is constructed in literary biography and mass media imagology" and compare it with their own conception of "the interview society and an analysis of styles of the self". Similar to Musil, Kundera depicts his characters in micro-situations such as visiting a swimming pool or having dinner in a restaurant. Yet, while Musil writes about a specific milieu, Kundera's text brings together anecdotes of characters living in different times and places. ${ }^{12}$ The novel's structure is navigated by a single concept, which is elaborated upon from diverse situational perspectives. In this sense, the novel resembles an anthropological study: it focuses on an abstract conception of a social phenomenon common for a particular society (the Western consumerist society in this case), which is then illustrated by diverse situational "vignettes". These vignettes, nevertheless, are not of a merely illustrative character, but they are crucial for understanding the phenomenon. Kundera's imagology is "conceptualized" as a whole bundle of anecdotes, images, impressions, metaphorical depictions of experience, dramatized scenes, etc. We cannot merely paraphrase (Ward, 1986: 335), digest, or translate Kundera's novel as a coherent set of definitions based on sociological discourse. Immortality's ability to represent a general social phenomenon is established by a specific formal arrangement of every single paragraph, sentence, and word, and their aesthetic effect upon the reader.

12. Such as Wolfgang Goethe and Ernest Hemingway. 


\section{Existential Understanding and Zeitgeist Coming Together}

Inspired, along with other texts, by Goffman's adaptation of Melville, Alworth (2015: 2; emphasis mine) asks "How does literary fiction theorize social experience?" When answering this question, Alworth (2015: 2-4) suggests that sociologists should eschew the "symptomatic reading" based on "hermeneutics of suspicion" and instead seek to apprehend "the way that literary texts assemble an impression of the social form". It is in the reading where the specificity and generality of perspectives-the experiential evidence and abstract theoretical interpretation in the sense of Reed-are entangled into a single sensation of social form. It is in the reading, not before or after the reading, where social knowledge in literature comes into existence. Any ideologies involved cannot be addressed outside of the reading itself. Alworth (2015: 11) suggests "to discover the sociology in literature", because sociology is "to be found in the way that literature itself grounds social experience, the way that it imagines sociality in situ".

To tackle the problem of "social form" mediated by literature, Alworth (2015: 10) brings to light György Lukács' (1970/1936: 115) treatment of Flaubert's Madame Bovary, where, according to Lukács, "the minute description of setting is absolutely essential to ... the comprehensive exposition of the social milieu". Here, the question of social form"how to represent society and its constituents" - is approximated with the question of realistic prose favored by Lukács of "how to represent the palpable world" (Alworth, 2015: 10). The comprehensive account of social phenomena is delivered through the realistic and detailed description of Emma Bovary's country house and her possessions, furniture, garden, clothing, etc., carefully orchestrated into a condensed impression mediated to the reader. Just like in Geertz's Deep Play, it is a thick description of the myriad of tiny details that altogether bring about a meaningful interpretation of broader social life. This aesthetically pleasing thick description, a blend of facts and theoretical constructs cemented together by textual devices, is Flaubert's way of theorizing the social world in his novel.

This way of the coming together of the abstract and the detailed is well visible in the realistic genre. Madame Bovary and Pride and Prejudice reach the effect of "vraisemblance" (Atkinson, 1990: 39) upon the reader via depicting realistic sceneries and events, so "there is the extent to which the text masks its own textual conventions, appearing to conform to a 'reality". Here it is instructive to recall a well-known critique of Lukács' conception of representativity (Harrington, 2004: 124-129; Laurenson, Swingewood, 1972: 53-56). Lukács considered writers such as Proust and Musil as incapable of depicting society "as a whole" because he found modernistic writing to portray "man as fragmented and partial" - thus replacing realistic "totality" by modernistic "subjectivity" (Ibid.: 55f.). However, Lukács did not see that by depicting ambivalence and elusiveness of human existence, authors like Musil strived to grasp the general qualities of modern societies. As Peter Berger (1970: 213) suggests, "[w] hat Musil attempted in his gigantic work was nothing less than a solution of the problem of reality from the perspective of modern consciousness". By inventing new formal means that most adequately grasp and mediate social life in a given time and place, the literary texts keep up with changing reality. 
Perhaps the most famous example of such an account in modern literature is James Joyce's Ulysses (1992/1922). This voluminous piece tells a story of a single character, Leopold Bloom, pacing through his ordinary day in the city of Dublin. Although the spatiotemporal framework is very limited-a single day in a single city - the novel's representativity goes way beyond that. Franco Moretti (1996) calls this phenomenon "modern epic". While the epic is traditionally connected with folk narratives and oral cultures, the modern epic shifts some of these pre-modern qualities into modern literature. The mythical narratives such as the Homeric epics of ancient Greece or epic poems of the Middle Ages contained in itself a social experience fundamental for the whole collectivity-the codification of a cosmological order. The modern literature, on the other hand, "by describing subjective phenomena" poses a question "about the unsharability of experience during a period of social fracture and epistemological uncertainty" (Zhang, 2014: 53). Even though modern literature is only capable of fragmented and subjectivized accounts of the social world, it can nevertheless communicate "cosmic, infinite and mythical" through "the minutiae of everyday life and the finite fleeting experiences of an insignificant individual" (Harrington, 2002a: 57).

Modern literature takes account of subjective feelings and sensations through perpetual tension. The effort to describe the "feeling of being unable to describe what one is feeling" (Zhang, 2014: 55) fuels the imaginative powers of literary authors and encourages them to invent new means of communication: new metaphors, new textual forms, and new sounds and rhythms. The artistic practice, that is, the way Ulysses is written, is an indivisible part of Joyce's theorizing the sociality. Joyce's "recreation" of social life "is so complex, alternately baffling and fascinating to so many readers, precisely because of how Joyce constructs setting as a relation between the metropolis and mental life, between the commotion of midmorning Dublin and Bloom's processes of cogitation" (Alworth, 2015: 17; emphasis original). Ulysses, just like Man Without Qualities and Remembrance of Things Past can "communicate a specific feature of our experience of transience and temporality in the modern world: the sense in which the merely apparent, transitory and local can at the same time encapsulate the collective and universal" (Harrington, 2002a: 58). We can see how the two types of social knowledge-existential understanding and representation of social phenomena-are intertwined and support each other. The texture of social life, aesthetic, and non-discursive aspects of social experience facilitate the understanding of the "big picture" of whole societies. 


\section{Conclusion: What Needs to be Done Next}

"Like theories, fictional texts refer as systems, and
just as in physics it is often impossible to set apart
'genuinely' referential elements from the math-
ematical apparatus, in fiction one does not always
need to keep track of pretended and genuine state-
ments, since global relevance is apparent in spite
of such distinctions." (Pavel, 1986: 25)

Dmitry Kurakin (2010: 230) talks about literary fiction as a "meaningful life laboratory, which makes it possible to observe purified situations of strong emotional involvement within concrete meaningful structures in order to disclose those mechanisms". The laboratory metaphor is useful in our thinking of literature as an artificial space occupied by creatures and entities invented by the author. Just like in a real laboratory, there is a certain degree of constructedness involved, which nevertheless does not prevent the experimenter from claiming knowledge about the non-artificial world outside the laboratory. A worker in a laboratory creatively combines natural samples with all kinds of tools, measuring devices, artificial substances, etc., to bring about interesting new findings. Similarly, the literary author employs imagination to combine real-life experience with various formal means of textual communication, such as metaphors, descriptions, word pace and rhythm, etc., to reveal something new.

Kurakin (2010) illustrates this with a short story "Funes, the Memorious" by J. L. Borges (1962). The main character, Funes, has a memory that remembers everything about his "inner experiences as well as outer", so he remembers not only "every leaf of any tree ever seen, but every time he thought about it" (Kurakin, 2010: 228). By granting him this special feature, Borges shows how the life could look without the capacity to forget and without the ability to emotionally mark and hierarchize our memory. Borges sets an artificial arrangement of characters, things, and events to direct reader's attention toward an abstract conception of a phenomenon, which is inherent to every human.

As Ricoeur (1976) stresses, the ability to communicate findings about real things does not happen despite the fictional character of the text but because of it. The artificiality involved in making a fictional story is analogous to the artificiality in conducting sociological research. In this sense, metaphors, aesthetic devices, and fictional entities serve the same purpose as a theory in sociological research. Thanks to the theory, the scientist can isolate and focus attention on the phenomenon of interest. The literary writer does nothing else. The "purified situations" Kurakin (2010: 230) talks about are but artificially created situations in which the author concentrates on a particular issue and "magnifies" it. From the phenomenological point of view, the author "brackets out" unnecessary noise and pays full attention only to the things relevant for the project. That is when the author brings "evidential" and "theoretical" signifiers together in order to tell of abstract and general (deeper understanding) through concrete and particular (thickly described facts) (cf. Reed, 2011: 92ff.). 
Should cultural sociology take literature seriously, it must abandon the false hierarchy between "real" and "fictional". A necessary epistemological step towards a strong program in the sociology of literature is to acknowledge that literature has an ability to come up with social knowledge by means of its own autonomous ways of communication. Sociological studies of literature have hitherto embraced two major attitudes towards the lyrical: either absolute ignorance (in favor of production and reception) or sacred reverence (making literature somewhat detached, strange, almost untouchable) (see Váňa, $2 \mathrm{O} 2 \mathrm{ob}$ ). However, this syndrome of lyrical exceptionalism can be overcome. We can start by recognizing how exactly the "aesthetic knowing" (Reed, Alexander, 2009: 31) through literature is different from-but also similar to-the more "rationalized" and "rigorous" knowing in social sciences. To stress that literature and sociology embrace a similar kind of imaginative theorizing is not to claim that literature and sociology are alike (cf. Nisbet, 1962: 73). However, if we want to access the abundance of social knowledge lingering within fictional texts, we cannot simply reduce literature to its social surrounding or translate it into sociological discourse. Cultural sociology has the potential to use the specificity of literary communication to its advantage-to access subtle and ambiguous but also highly condensed and abstract accounts of social life, which are often elusive to social scientific inquiry. The next task for developing a strong program in the sociology of literature is to find the theoretical-methodological key $^{13}$ to unlock the wealth of social knowledge mediated by literature's unique forms of expression.

\section{Funding}

This paper resulted from the project "Sexuality: Attitudes and Behaviour across Generations", number MUNI/A/1158/2019, which was supported by the Ministry of Education of the Czech Republic as part of its scheme advancing research at universities.

\section{References}

Abbott A. (2007) Against Narrative: A Preface to Lyrical Sociology. Sociological Theory, vol. 25, no 1, pp. 67-99.

Adorno T. (1991/1958) The Essay as Form. Notes to Literature: Volume 1, New York: Columbia University Press, pp. 3-23.

Alexander J. C. (1982) Theoretical Logic in Sociology, Volume 1: Positivism, Presuppositions, and Current Controversies, Berkeley: University of California Press.

Alexander J. C. (2011) Fact-Signs and Cultural Sociology: How Meaning-Making Liberates the Social Imagination. Thesis Eleven, vol. 104, no 1, pp. 87-93.

Alexander J. C., Smith P. (2003) The Strong Program in Cultural Sociology: Elements of a Structural Hermeneutics. The Meanings of Social Life: A Cultural Sociology, Oxford: Oxford University Press, pp. 11-26.

13. Part of this project was elaborated in Váňa (2020a). 
Alworth D. J. (2014) Melville in the Asylum: Literature, Sociology, Reading. American Literary History, vol. 26, no 2, pp. 234-261.

Alworth D. J. (2015) Site Reading: Fiction, Art, Social Form, Princeton: Princeton University Press.

Atkinson P. (1990) The Ethnographic Imagination: Textual Constructions of Reality, London: Routledge.

Atkinson P., Silverman D. (1997) Kundera's Immortality: The Interview Society and the Invention of the Self. Qualitative Inquiry, vol. 3, no 3, pp. 304-325.

Baert P., Rubio F. D. (2009) Philosophy of the Social Sciences. The New Blackwell Companion to Social Theory (ed. B. S. Turner), Malden: Blackwell, pp. 60-80.

Bartmański D., Binder W. (2015) Being and Knowledge: On Some Liabilities of Reed's Interpretivism. Czech Sociological Review, vol. 51, no 3, pp. 499-511.

Becker H. S. (1982) Art Worlds, Berkeley: University of California Press.

Becker H. S. (2007) Telling about Society, Chicago: University of Chicago Press.

Berger P. L. (1970) The Problem of Multiple Realities: Alfred Schutz and Robert Musil. Phenomenology and Social Reality (ed. M. Natanson), Dordrecht: Springer, pp. 213233.

Borges J. L. (1962) Funes, the Memorious. Ficciones, New York: Grove Press, pp. 107-116.

Bourdieu P. (1996) The Rules of Art: Genesis and Structure of the Literary Field, Stanford: Stanford University Press.

Brady I. (2004) In Defense of the Sensual: Meaning Construction in Ethnography and Poetics. Qualitative Inquiry, vol. 10, no 4, pp. 622-644.

Butte G. (2004) I Know that You Know that I Know: Narrating Subjects from Moll Flanders to Marnie, Columbus: Ohio State University Press.

Delanty G. (2009) The Foundations of Social Theory. The New Blackwell Companion to Social Theory (ed. B. S. Turner), Malden: Blackwell, pp. 19-37.

Erasga D. S. (2010) When Story Becomes Theory: Storytelling as Sociological Theorizing. Asia-Pacific Social Science Review, vol. 10, no 1, pp. 21-38.

Felski R. (2008) Uses of Literature, Malden: Blackwell.

Freeman M. (2014) The Hermeneutical Aesthetics of Thick Description. Qualitative Inquiry, vol. 20, no 6, pp. 827-833.

Geertz C. (1973) The Interpretation of Cultures: Selected Essays, New York: Basic Books.

Geertz C. (1983) Local Knowledge, New York: Basic Books.

Greenblatt S. (1997) The Touch of the Real. Representations, vol. 59, July, pp 14-29.

Griswold W. (1987) The Fabrication of Meaning: Literary Interpretation in the United States, Great Britain, and the West Indies. American Journal of Sociology, vol. 92, no 5, pp. 1077-1117.

Harrington A. (2002a) Knowing the Social World through Literature: Sociological Reflections on Robert Musil's The Man Without Qualities. International Journal of Social Research Methodology, vol. 5, no 1, pp. 51-59.

Harrington A. (2002b) Robert Musil and Classical Sociology. Journal of Classical Sociology, vol. 2, no 1, pp. 59-76. 
Harrington A. (2004) Art and Social Theory: Sociological Arguments in Aesthetics, Cambridge: Polity Press.

Hoggart R. (1966) Literature and Society. American Scholar, vol. 35, no 2, pp. 277-289.

Joas H., Knöbl W. (2009) Social Theory: Twenty Introductory Lectures, Cambridge: Cambridge University Press.

Joyce J. (1992/1922) Ulysses, London: Penguin Books.

Knorr Cetina K. (2014) Intuitionist Theorizing. Theorizing in Social Science: The Context of Siscovery (ed. R. Swedberg), Stanford: Stanford University Press, pp. 29-60.

Krause M. (2019) What is Zeitgeist? Examining Period-Specific Cultural Patterns. Poetics, vol. 76, pp. 1-10.

Kundera M. (1991) Immortality, London: Faber \& Faber.

Kundera M. (2005) The Curtain, New York: Harper Collins.

Kurakin D. (2010) Literature as a Meaningful Life Laboratory. Integrative Psychological and Behavioral Science, vol. 44, no 3, pp. 227-234.

Kuzmics H. (2015) Using Fiction as Sociology: How to Analyze Emotions with the Help of Novels. Methods of Exploring Emotions (eds. H. Flam, J. Kleres), London: Routledge, pp. 25-35.

Lahire B. (2015) Literature is Not Just a Battlefield. New Literary History, vol. 46, no 3, pp. 387-407.

Laurenson D., Swingewood A. (1972) The Sociology of Literature, London: MacGibbon \& Kee.

Lepenies W. (1988) Between Literature and Science: The Rise of Sociology, New York: Cambridge University Press.

Lukács G. (1970/1936) Narrate or Describe? A Preliminary Discussion of Naturalism and Formalism. Writer and Critic and Other Essays, New York: Merlin Press, pp. 110-148.

Macé M. (2013) Ways of Reading, Modes of Being. New Literary History, vol. 44, no 2, pp. 213-229.

Melville H. (1956) White-Jacket; or, The World in a Man-of-War, New York: Grove Press.

Merton R. K. (1993) On the Shoulders of Giants: A Shandean Postscript, Chicago: University of Chicago Press.

Mills C. W. (1959) Sociological Imagination, New York: Oxford University Press.

Moretti F. (1996) Modern Epic: The World System from Goethe to García Márquez, London: Verso.

Musil R. (1953) The Man Without Qualities (3 vols.), London: Minvera.

Nisbet R. A. (1962) Sociology as an Art Form. Pacific Sociological Review, vol. 5, no 2, pp. $67-74$.

Pavel T. (1986) Fictional Worlds, Cambridge: Harvard University Press.

Peirce C. S. (1992) Training in Reasoning. Reasoning and the Logic of Things, Cambridge: Harvard University Press, pp. 181-196.

Popper K. (2005/1934) The Logic of Scientific Discovery, London: Routledge.

Proust M. (2002) In Search of Lost Time (6 vols.), London: Penguin Books. 
Ricoeur P. (1976) Interpretation Theory: Discourse and the Surplus of Meaning, Fort Worth: TCU Press.

Ricoeur P. (2016/1981) Hermeneutics and the Human Sciences, New York: Cambridge University Press.

Reed I. A. (2010) Epistemology Contextualized: Social-Scientific Knowledge in a Postpositivist Era. Sociological Theory, vol. 28, no 1, pp. 20-39.

Reed I. A. (2011) Interpretation and Social Knowledge: On the Use of Theory in the Human Sciences, Chicago: University of Chicago Press.

Reed I., Alexander J. C. (2009) Social Science as Reading and Performance: A Cultural-Sociological Understanding of Epistemology. European Journal of Social Theory, vol. 12, no 1, pp. 21-41.

Sanderson S. K. (2005) Reforming Theoretical Work in Sociology: A Modest Proposal. Newsletter of the ASA Theory Section, vol. 28, no 5, pp. 1-4.

Smith P. (2004) Marcel Proust as Successor and Precursor to Pierre Bourdieu: A Fragment. Thesis Eleven, vol. 79, no 1, pp. 105-11.

Swedberg R. (2014) From Theory to Theorizing. Theorizing in Social Science: The Context of Discovery (ed. R. Swedberg), Stanford: Stanford University Press, pp. 1-28.

Sztompka P. (2004) Shaping Sociological Imagination: The Importance of Theory. Self, Social Structure, and Beliefs: Explorations in Sociology (ed. J. C. Alexander), Berkeley: University of California Press, pp. 254-267.

Thumala Olave M. A. (2018) Reading Matters: Towards a Cultural Sociology of Reading. American Journal of Cultural Sociology, vol. 6, no 3, pp. 417-454.

Turner Ch. (2010) Investigating Sociological Theory, London: SAGE.

Váňa J. (2020a) Theorizing the Social Through Literary Fiction: For a New Sociology of Literature. Cultural Sociology, vol. 14, no 2, pp. 180-200.

Váňa J. (2020b) More than Just a Product: Strengthening Literature in Sociological Analysis. Sociology Compass, vol. 14, no 6, pp. 1-16.

Ward J. P. (1986) Poetry and Sociology. Human Studies, vol. 9, no 4, pp. 323-345.

Williams R. (1960) Culture and Society: 1780-1950, New York: Anchor Books.

Zhang D. (2014) Naming the Indescribable: Woolf, Russell, James, and the Limits of Description. New Literary History, vol. 45, no 1, pp. 51-70. 


\title{
Художественная литература и социальное знание: на пути к «сильной программе» в социологии литературы
}

\author{
Ян Вана \\ Аспирант, департамент социологии, факультет социальных наук, Масариков университет \\ Адрес: Joštova 218/10, Brno, 602 oo, Czech Republic \\ E-mail:vana@fss.muni.cz
}

Следуя «сильной программе» социологии культуры, я предлагаю сильную программу социологии литературы, которая рассматривает литературные произведения как культурные объекты, обладающие относительной автономией, и «независимые переменные». Чтобы обрисовать эпистемологические основы новой исследовательской программы, я сравниваю, как возникает социальное знание через социологический текст и текст художественной литературы. Основываясь на книге Айзека Рида «Интерпретация и социальное знание», я обсуждаю представление социальной реальности в интерпретативных исследованиях. Для обоснования литературной автономии, я обрисовываю некоторые аспекты, общие для социальной теории и художественной литературы. Меня в основном интересует, как социальная теория и художественная литература передают своим читателям социальные знания через эстетический опыт. Я выделяю две основные категории социального знания, опосредованного литературой: экзистенциальное понимание и Zeitgeist (дух времени). Обсуждая социологическую трактовку нескольких романов, я смотрю на то, как эти две категории переплетаются и, в сочетании друг с другом, создают красочное, чувствительное, но также надежное и глубокое социальное знание, которое объединяет эстетические, экзистенциальные и недискурсивные аспекты социального опыта вместе с «большой картиной» обществ целиком. Я утверждаю, что только преодолев предполагаемую в социологии неполноценность литературы она может полностью реализовать свой потенциал в понимании смыслов социальной жизни.

Ключевые слова: социология литературы, культурсоциология, социальное знание, социальная теория, теоретизирование, эстетический опыт, художественная литература 